\title{
LEARNING BY BIDDING: EVIDENCE FROM A LARGE-SCALE NATURAL EXPERIMENT
}

\author{
Jan Hanousek \\ Evžen Kočenda
}
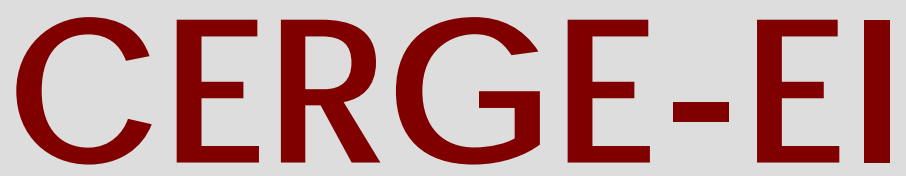

Charles University Centerfor Economic Research and Graduate Education Academy of Sciences of the Czech Republic Ec onomic Institute 


\title{
Working Paper Series (ISSN 1211-3298)
}

\section{Learning by Bidding: \\ Evidence from a Large-Scale Natural Experiment}

\author{
Jan Hanousek \\ Evžen Kočenda
}

CERGE-EI

Prague, March 2005 
ISBN 80-7343-040-1 (Univerzita Karlova v Praze, CERGE)

ISBN 80-7344-029-6 (Národohospodářský ústav AV ČR, Praha) 


\title{
Learning by Bidding: \\ Evidence from a Large-Scale Natural Experiment
}

\author{
Jan Hanousek * \\ and \\ Evžen Kočenda *
}

\begin{abstract}
Learning is a subject of intense research in experimental economics. We contribute to this debate by presenting persuasive evidence that learning took place among uninformed heterogeneous agents on a quasi-stock market during a large-scale natural experiment that by size, incentives, and variation belongs among the largest experiments ever conducted. To detect and quantify learning we develop new measures of individual performance during the bidding process when prices of goods vary over succeeding stages of bidding.
\end{abstract}

\begin{abstract}
Abstrakt
Proces učení je tématem intenzivního výzkumu experimentální ekonomie. Tímto článkem rozšiřujeme odbornou diskuzi, nebot' $v$ něm přesvědčivě ukazujeme, že $\mathrm{k}$ procesu učení došlo mezi velkým množstvím různorodých účastníků kvazi akciového trhu v průběhu velkého prrirozeného experimentu. Tento experiment patří co do velikosti, hmotných pobídek a různorodosti účastníků mezi nejrozsáhlejší experimenty provedené vůbec. Abychom mohli proces učení nalézt a hodnotově vyjádřit, navrhli jsme nové měřitelné charakteristiky individuálního výkonu během cenotvorného procesu v jehož průběhu se ceny komodit mění.
\end{abstract}

Keywords: learning, natural experiment, auction, stock market, privatization, heterogeneous agents, transition

JEL Classification: C14, C93, D44, D82, D83, G14, P43

* CERGE-EI, Prague; CEPR and WDI

Part of this paper was written while Hanousek and Kočenda were Visiting Professors at the WDI of the University of Michigan Business School. The hospitality of the WDI is greatly acknowledged. Hanousek and Kočenda hold Citibank Professorships at CERGE-EI, a joint workplace of Charles University and the Academy of Sciences of the Czech Republic.

For helpful comments we are grateful to Glenn Harrison, Peter Katuščák, John List, Andreas Ortmann, Ondřej Rydval and Petr Zemčík. We have also benefited from several presentations. Thanks go to Laura Mentz for editing the paper. The usual disclaimer applies. 


\section{Introduction}

Learning as a topic of intense research in experimental economics has gained currency as experimental economics itself made advances into the fields of finance and asset markets (see Friedman, Harrison, and Salmon, 1984; Kagel and Roth, 1997) and risk assessment (see Holt and Laury, 2002; Harrison et al., 2005). In this paper, we present persuasive evidence that learning took place among originally uninformed agents who had strong incentives to learn on a quasi-stock market during a large natural experiment whose stakes compounded, on average, to several months of pay. By virtue of our experiment's design with multiple market periods which allow agents to learn based on accumulated experience, our results lend insights into the findings of Smith (1962) and List (2004c).

There exists a considerable amount of theoretical literature on learning, yet despite considerable advances, theoretical research on learning and evolution is halfempty without empirical support (see Weibull, 1995; Fudenberg and Levine, 1998; and Vega-Redondo, 2003, among others, for overviews). These empirics are almost exclusively driven by the experimental approach; results from learning in laboratory experiments are broadly discussed by Camerer (2003). He defines learning as "an observed change in behavior owing to experience" and argues for the use of experimental data since they "are a good way to test models of learning because control over payoffs and information means we can be sure what subjects know (and know others know, and so on), what they expect to earn from different strategies, what they have experienced in the past, and so forth" (Camerer, 2003, p.265).

Results from laboratory experiments suffer from obvious drawbacks: they are nearly always performed with relatively small samples of university students. ${ }^{1}$ In addition, monetary rewards for active participation in such experiments are frequently limited; this casts doubt on to what extent these experiments capture learning. ${ }^{2}$ Further, experiments that are small in size in terms of participants and in terms of earnings are usually also small in the choice set that participants face. In line with the above

\footnotetext{
${ }^{1}$ Groups of participants typically exhibit a relatively high degree of homogeneity, despite variation in gender, for example.

${ }^{2}$ Researchers have raised doubts whether a payment of, say $\$ 30$, provokes enough activity to warrant real world results. This critique could be simply restated as low gain for low effort.
} 
limitations, arguments stressing that incentives must be salient for experimental data to have meaning were voiced by Smith $(1976,1982)$, Harrison (1989), Smith and Walker (1993), Wilcox (1993), and Hertwig and Ortmann (2001). ${ }^{3}$

We are able to avoid these methodological problems by using data from a largescale natural experiment: a series of auction stages on a quasi-stock market to privatize more than 1600 state-owned enterprises. Participants in this experiment-ordinary citizens-were counted in the millions; a participation rate of $87 \%$ of eligible citizens minimizes possible sample selection bias. Our study is based on complete individual bidding data for a randomly drawn heterogeneous population of 5000 citizens. To the best of our knowledge, these data constitute one of the largest samples available worldwide that can trace each step of each individual during such a natural auction experiment. ${ }^{4}$ The rewards for participation in this experiment were substantial. The expected returns were several months' average salary, with the maximum returns being several years of average salary. ${ }^{5}$ In addition, individuals paid a participation fee equal to about one week of salary. Clearly, these incentives gave participating individuals strong incentives to learn.

Our paper thus contributes to the debate on learning in three ways. First, we supplement the theoretical literature on learning by bringing persuasive evidence that learning took place among uninformed heterogeneous individuals during the real-life auction-like process. Second, we base our evidence on a data set from a natural experiment that by size, incentives, and variation belongs among the largest

\footnotetext{
${ }^{3}$ These problems are quite understandable since the costs of experiments with large groups of individuals are extremely high and the conduct of such experiments poses other nontrivial problems: credible arrangement for all participants, and managing large numbers of individuals, to name but only two (for a related account see Harrison and List, 2004 or Carbone, 2004).

${ }^{4}$ There are previous experiments that use large samples. In early work Suppes and Atkinson (1960) reported gaming results from more than 1000 subjects. Harrison, Lau, and Williams (2002) estimated individual discount rates among 268 people. List (2003) observed the trading decisions across 148 subjects. Carbone (2004) engaged 498 participants in a comparison of the actual consumption strategy with the fully optimal strategy. In a fund-raising campaign designed as a field experiment List (2004a) engaged 1946 individuals. The experimental design in List (2004b) includes data gathered from more than 1100 market participants.

${ }^{5}$ These incentives are higher than those in Kachelmeier and Shehata (1992), where in the highest payoff condition, subjects earned three times their normal monthly revenue in the course of a two-hour experiment that was conducted in another transition economy, the People's Republic of China; or in Slonim and Roth (1998) where in an ultimatum game experiment in the Slovak Republic, financial incentives were varied by a factor of twenty-five.
} 
experiments ever conducted. Third, in order to detect and quantify learning we develop new measures of individual bidding performance based on the distance of individual performance from performance of two benchmarks (market portfolio and informed investor); these measures account for varying prices of goods (shares) available in succeeding stages of bidding.

Using a non-parametric test we compare individual outcomes between different rounds of bidding on a proxy stock market and show that significant learning is observed among relatively uninformed individuals. We conjecture that the extraordinary incentives that participants faced was the key factor driving our results.

The paper is organized as follows: section 2 describes the natural experiment and the data; section 3 defines learning formally and reports the empirical results. Section 4 briefly concludes.

\section{Natural Experiment and Data}

The data used in this paper are from a natural experiment: the bidding process to acquire shares in privatized firms known as the voucher scheme (see section 2.1 for details). A natural experiment takes place when naturally-occurring comparisons of one or more treatments with a baseline are observed (Harrison and List, 2004). The natural experiment may be contrasted with an ideal field experiment in which it is possible to observe a subject in a controlled setting but where none of the controls is perceived as being unnatural and where no deception is being made. Natural experiments are appealing sources of data since, despite the fact that such an experiment is not organized as an experiment per se, some event that arises in the real world happens to share critical characteristics with a field experiment.

Harrison and List (2004) expertly guide the reader through the landscape of field experiments and identify six criteria that define them. These are: i) the nature of the subject pool, ii) the nature of the information that the subjects bring to the task, iii) the nature of the commodity, iv) the nature of the task or trading rules applied, v) the nature of the stakes, and vi) the nature of the environment that the subject operates in. These criteria provide a convenient way to describe the essential characteristics of the natural experiment used as the source of our data. 
The characteristics, in the above order, can be depicted as: i) all citizens 18 years and older $^{6}$, ii) instructions on the bidding process and public information on privatized firms, iii) privatized firms (specifically, shares in privatized firms that could be sold for money after the end of the privatization scheme), iv) bidding based on publicly known rules, v) shares representing substantial (future) monetary value, and vi) an artificial market to proxy for the stock market. Below we describe the natural experiment and explain these characteristics in more detail.

So far all comparisons done on the voucher privatization scheme have used aggregated data, i.e., bids of all individuals were treated as the outcome of one (uninformed) agent. Such specifications do not take into account that the population of those individuals successfully placing their bids could vary significantly between rounds. Therefore, in order to analyze if individuals were able to learn and adjust their bidding behavior between rounds, it is imperative to deal with individual bidding data.

\subsection{Voucher scheme as a natural experiment}

The natural experiment itself was part of the massive privatization program administered in the Czech Republic in the first half of the 1990s under three different schemes: restitution, small-scale privatization, and large-scale privatization. The first two schemes began in 1990 and were most important during the early years of the transition. Large-scale privatization, by far the most important scheme, began in 1991, was completed in early 1995, and allowed for various privatization techniques. ${ }^{7}$ Small firms were usually auctioned or sold in tenders. Many medium businesses were sold in tenders or to predetermined buyers in direct sales. Most large and many medium firms were transformed into joint stock companies and their shares were distributed through voucher privatization (almost one-half of the total number of all shares of all joint stock companies was privatized in the voucher scheme), sold in public auctions or to strategic partners, or transferred to municipalities.

\footnotetext{
${ }^{6}$ Participation rate was $87 \%$ of eligible citizens. Thus, virtually no truncation is involved in our case.

7 The privatization process has been extensively described and analyzed. See e.g., Kotrba (1995); Valbonesi (1995); Hanousek and Kroch (1998); Kočenda (1999); and Filer and Hanousek (2001) among others.
} 
The voucher scheme was part of the large-scale privatization process. Two waves of voucher privatization took place in 1992-93 and 1993-94, respectively. ${ }^{8}$ During the scheme, a total of 1664 firms were privatized: 988 in the first wave, and 676 firms in the second wave plus 185 firms not fully privatized in the first wave. Our data come from the second wave. All Czech citizens over the age of 18 who resided in the Czech Republic ${ }^{9}$ could participate in the voucher process. For each wave every eligible citizen was authorized to buy a voucher book that contained 1000 investment "points" for 1000 crowns (about a week's wage). Before the bidding started, individuals had the option of assigning some or all of their points to Privatization Investment Funds (PIFs). These PIFs had to publish basic facts about both the founder and the investment strategy. This part of the scheme is usually called "pre-round" or "zero round". The voucher book contained investment points in values of 100, 200, 500 and 1000; therefore the smallest bid was 100 points (in other words an individual's portfolio could be diversified up to 10 different items).

When entering the voucher scheme, individuals had two basic strategies to choose from. One was to bid for a particular firm to exercise shareholder's rights of control. However, the limited number of voucher points that were available for each individual during the bidding process effectively prevented individual bidders from the possibility of exercising control over a privatized firm. ${ }^{10}$ Individuals' awareness about this fact thus made firms' shares perfect substitutes. Thus, the second strategy was to maximize cash revenues from the future sale of shares, receive dividend payments, or a combination of both.

After the pre-round, at the start of the bidding process, the public was given basic financial information about each enterprise to be transferred. The information

\footnotetext{
${ }^{8}$ Privatization of each state-owned firm was decided on the basis of an officially accepted privatization project. According to the law, all state-owned enterprises were selected either for the first or the second privatization wave, or they were temporarily exempted. Each selected firm had to submit an official privatization proposal that was usually crafted by the firm's management under the tutelage (and responsibility) of its sectoral ministry. Any domestic or foreign corporate body or individual was allowed to present a competing project that was to be considered on an equal footing to the official one.

${ }^{9}$ For the first wave in the Slovak Republic, as well, since only in 1993 Czechoslovakia was split into two independent nations: the Czech and Slovak Republics.

${ }^{10}$ After the voucher scheme ended, this assumption proved to be accurate. Resulting ownership was simply too dispersed to allow individual shareholders to exercise control.
} 
included employment, wages, capital, sales, costs, profit or loss, liabilities, foreign trade, ownership structure, etc. and was published in the special periodical "Kuponova Privatizace" (i.e. Voucher Privatization). Following the pre-round the actual bidding started. In this process citizens and PIFs used their voucher points to buy shares of available firms in a series of price-administered bidding rounds. ${ }^{11}$ To avoid end of game problems, the total number of rounds was not set. Nevertheless, observers suspected that the total number of bidding rounds should be between 3 and 7. The bidding scheme was by no means a standard auction, since investors' bids were quantities and the prices were in fact administered by the privatization authority. ${ }^{12}$

Each bidding round was divided into four stages. In the first stage participants were told the administered price of the shares of each firm and the number of shares offered. Participants then bid for shares of their preferred firms. The third stage meant collecting, matching and analyzing the bids. The last stage, in fact, coincided with the first stage of the next round; the results of the bidding were announced and the Pricing Committee set the prices for the next round.

The bidding rounds continued until the privatization authority revealed the end of the wave when a negligible proportion of unsold shares along with disposable investment points remained. The final stage of voucher privatization was the real transfer of the purchased shares. For each participant, a share account at the Central Register was created. Those individuals who allocated part or all 1000 points to PIF(s) obtained the shares of PIFs immediately after the issue. Shares of firms obtained by

\footnotetext{
${ }^{11}$ A Pricing Committee in the Ministry of Finance adjusted prices between each round primarily using an excess demand rule. The sequential character of the bidding and closed-economy character of the auction prevented incentives for speculation from materializing. The announced goal of this commission was to adjust prices so that by the end of the process citizens had used all their points while distributing as many shares as possible. For details see Filer and Hanousek (2001).

${ }^{12}$ Czech voucher privatization thus resembled, but was not identical to, any classical market mechanism design. It was not a Walrasian tâtonnement since demands were satisfied prior to determination of the equilibrium price and there was no recontracting. It bears some resemblance to a multi-unit Dutch auction, although there were several key differences including the fact that the initial price was set at a supposed approximation of the true equilibrium price rather than a price higher than the reservation price of any individual bidder. For more details see Hanousek and Kroch (1998) and Filer and Hanousek (2001).
} 
individuals during the bidding process were traded on the capital market after the end of the privatization scheme. ${ }^{13}$

From the above outline it is evident that the bidding scheme was a way to establish market prices where there was no market, by using - in a sequential processa market response to adjust administered prices. Although the prices are not market prices, one can consider observed demand to be a market response to the set prices.

\subsection{The rules for accepting bids}

The rules for accepting bids were as follows (criterion vi) ${ }^{14}$ :

1. Prices in the first round of the wave were equal for all stocks (since the number of shares issued was determined by a firm's book value). ${ }^{15}$

2. In each successive round, prices were adjusted up or down as a function of the excess demand for or supply of the stock in the previous round. ${ }^{16}$

3. Price (number of points per share) was administered by the Pricing Committee, which never publicly revealed its algorithm for adjusting share prices between rounds. It was generally noted and observed that prices would rise for shares in excess demand and fall for shares in excess supply. ${ }^{17}$

4. If bids for a firm did not exceed its supply of shares, the demand was satisfied and the remaining shares were deferred to the next round.

5. If the demand for a firm's shares exceeded supply by less than $25 \%$ and the clearing of the market could be realized by prorating the PIFs' demand, then individual investors had their demand met while PIFs were rationed proportional to their

\footnotetext{
${ }^{13}$ Shares not allocated by the voucher scheme could be sold directly to a chosen buyer or offered to the general public on the securities market.

${ }^{14}$ For ease of accessibility we provide the bidding rules in a brief narrative. Based on Aggarwal and Harper (2000) we supply formal description of the auction rules in the technical Appendix.

${ }^{15}$ For the first round of the second wave - our experiment - the share price was set uniformly across firms at 2 shares per 100 points, since the number of shares assigned to each firm was based on the accounting value of the firm, so that each share represented the same book value (about 1200 crowns) for every enterprise.

${ }^{16}$ See Hanousek and Kroch (1998) and Valbonesi (1995).

${ }^{17}$ Note that prices would be increased in some cases for those shares whose excess supply was small relative to the mean market's excess supply. Moreover, one could expect that the number of unsold shares was significant for price pattern as well (Hanousek and Kroch, 1998).
} 
bids. In such cases, all shares were sold and the firm was not available for purchase in the succeeding rounds.

6. If demand exceeded supply by more than $25 \%$, then no bids were accepted and all shares were deferred to the next round. Theoretically, bidding for firms in excess supply means overpricing, but no bids should be accepted under excess demand.

\subsection{Information asymmetries}

In light of the above rules it comes as no surprise that the voucher scheme involved a certain degree of information asymmetry among its participants. We observe: 1) Asymmetry in information available to the agents. Empirical studies show that PIFs had more accurate information when compared to the public information used by the individual investors (see Hanousek and Kroch, 1998 and Filer and Hanousek, 2001). 2) Asymmetry in the scheme in between rounds. According to the bidding rules, if bids for a firm did not exceed its supply of shares, these orders were satisfied and the remaining shares were offered in the next round. But if the demand exceeded supply, then no bids were accepted and all shares were deferred to the next round. ${ }^{18}$

3) Asymmetry in rules for accepting the bids. In the case of slight excess demand (less than 25\%), the demand of PIFs was prorated in order to make demand and supply equal. The demand of individual investors remained unchanged, though.

The bidding process involved two groups of agents. The first group were ordinary citizens who can be characterized as uninformed heterogeneous agents since they possessed only limited prior knowledge of the process itself and had access only to the publicly available facts about firms. Privatization Investment Funds (PIF), as the second group, were informed agents that were equipped with teams of analysts and were believed to frequently possess non-public information (see Hanousek and Kroch, 1998, and Filer and Hanousek, 2001). ${ }^{19}$

A unique feature of the voucher process that makes it easy to control for publicly available information was the collection of a uniform set of information for

\footnotetext{
${ }^{18}$ There was a special regulation related to the size of the excess supply: if demand exceeded supply by less than $25 \%$, then the shares would be allocated by an equi-proportional cut in shares to PIFs.

${ }^{19}$ All known studies of the bidding process within the voucher scheme treat individuals as a group using aggregated data.
} 
every firm that was made available to bidders in either published or electronic form (criterion ii). Hanousek and Kroch (1998) found that this public information is important in explaining demand in the early rounds of the process but has no additional explanatory power once price is controlled for in later rounds. More interesting for our purposes is their finding that the demand for a firm by individuals was strongly influenced by demand for that firm by investment funds in previous rounds (information that was widely available in the local daily press) even after controlling for price and other public information. ${ }^{20}$ This suggests that individuals may have believed that the market was not efficient and that funds had additional non-public information.

\subsection{Data}

Our data come from the second wave of the voucher scheme. The timing of the second wave is depicted in Table 1 . When we consider the amount of state property to be privatized through this method it is clear that the voucher scheme was an extremely fast and dynamic process. The time span from the beginning of the bidding process to the shares' emission was about a year.

More than 6.16 million individuals participated in the second wave of the voucher scheme. Out of this total, 3.96 million (64.3\%) assigned their points into PIFs and about 2.2 million $\left(35.7 \%\right.$ ) bid on their own. ${ }^{21}$ Our data sample consists of detailed individual bidding information of 5000 citizens randomly selected out of the 2.2 million who decided to bid all their (1000) points individually and not through the PIFs. ${ }^{22} \mathrm{We}$ assume that, in general, these individuals were eager to participate actively in the scheme and they had a confidence in themselves. Moreover, every individual in our sample has exactly the same starting conditions (1000 points available). Many of these

\footnotetext{
${ }^{20}$ Hung and Plott (2001) show in a simplified case that when a clear pattern is present, individuals tend to discount their private signal and follow the herd instead. Our results (see below) do not support the herding effect, e.g. individuals do not bid only for firms for which the PIFs bid initially.

${ }^{21}$ In the first and second wave respectively, about $28 \%$ and $36 \%$ of points were used for direct bidding by citizens; the rest was deposited with the PIFs. The increase in the direct bidding participation rate should be credited to the fact that after the first wave citizens realized that they actually received shares (in privatized firms) that could be sold for cash on the secondary market. For a detailed account on the performance and governance of the PIFs see Kotrba, Kočenda, and Hanousek (1999).

${ }^{22}$ Random sampling was random also in the sense that selection did not involve individuals in any way pertaining to their characteristics. Sampling was based on anonymous ID numbers of voucher books, which certifies the representatives of our sample.
} 
individuals might have participated in the first wave of the voucher scheme. Unfortunately, we are not able to identify them. Given the higher participation rate of individuals in the second wave, we conjecture that the majority of these individuals participated also in the first wave. Therefore, there is a high likelihood that most of the participants were familiar with the bidding procedure from the first wave (of the voucher scheme); this attribute is similar to a warming-up phase common in laboratory experiments before an experiment officially begins.

The bidding data trace in detail every move of each individual during the bidding process. As complementary data we have aggregate information on bidding made by PIFs. Since the PIFs possessed better abilities to process all available information plus possible private information, they are a convenient representation of an informed investor. As for the individual investors, their aggregated behavior is illustrated in the following Tables 2-4. The bidding process started each round with the number of voucher points that were at the disposal of the individual investors. Table 2 shows proportions of points available at the beginning of each round. Obviously, at the beginning of the first round all individuals possessed the complete quota of 1000 points. We see that with each round the proportion of individuals who still had some points to bid decreases, which means that these individuals were able to allocate their points. The relative proportion of those who did not bid up to the last (sixth) round decreases and the proportion of those left with fewer than 100 points (minimum required to make a bid) increases over time. In the latter case we are talking about fewer than 30 individuals, though. Since the voucher scheme was a "closed economy" in the sense that voucher points could be used only in and during this scheme and after the final round the points had zero value, it was better to allocate the points wrongly in the last round than not to allocate them at all.

At the beginning of each subsequent round the new proportion of available points was determined by the two steps. First, based on the information available, individuals made their decisions and bid their points in order to obtain shares of various firms; the proportions of these bids are shown in Table 3 (points bid). Panel A shows these proportions related to the whole sample of individuals, while panel B accounts for proportions of points related to the part of our sample that still possessed at least 100 
points needed to make a bid. Thus, in panel B we do not consider those individuals who already spent all their points below the 100 point threshold. For completeness we also present basic statistics (mean and standard deviation) of absolute numbers of points that were bid in each round.

Second, bids were thereafter processed in accordance with the bidding rules. Table 4 shows the proportion of the bids that were actually processed and for which the shares were sold; these are points spent in each round and represent the reduction of available points for the subsequent round. The remaining points after this step naturally constitute the proportion of available points for the next round. Again panel A in the Table 4 shows proportions related to the whole sample and panel B shows these proportions with respect to individuals who still had enough points to bid. As in the previous layout, the bottom part of each panel contains basic statistics (mean and standard deviation) of absolute numbers of points that were spent in each round.

\section{Learning}

\subsection{Definition and measures}

From a summary of Tables 2-4 we see that individuals were able to allocate their points in a manner that would not waste these points. However, from the Tables we can derive information neither about the potential "profitability" of these allocations, nor about whether the individuals have been learning. To do so we would need to connect the standard definition of learning with some measures that would be able to capture the learning based on the data from our natural experiment.

Learning during the bidding process of the voucher scheme can be tied to the model of experience-weighted attraction (EWA) learning that was designed by Camerer and Ho (1999) and combines the most appealing elements of reinforcement and weighted fictitious play (see Camerer, 2003, for an overview of learning models). In our experiment the reinforcement part of the model comes in the form of the feedback after the end of each round (of the voucher scheme) when individuals learned how they bid (if they bid in excess supply or demand) and how the privatization funds bid. Thus, an individual's past strategy enters as information about points bid and spent (revenue) rather than in as information about each particular firm (see Section 2). Since we have 
several hundreds of firms and five thousand individuals, the problem of identification arises and we are not able to proceed in the usual way that would involve the above model. Therefore, we adopt the following strategy.

Learning is defined by Camerer (2003, p.265) as an "observed change in behavior owing to experience". If the individuals in our data sample were learning, then, owing to experience, they should change their bidding strategy over the course of successive rounds to improve their performance. In order to detect (or refute) learning we have to define appropriate measures of individual performance. In doing so we have to account for the fact that an individual could start her/his bidding in any round and continue until the very end of the scheme or until s/he had no points left, and that prices and selection of available shares were changing across rounds.

As described earlier, the voucher scheme used a specific "currency" - voucher points - with which participants could buy shares of privatized companies. After the scheme, unspent vouchers had zero value. Unless all individuals bid only for the same set of shares, we cannot measure and compare their performance between rounds using voucher points. There exists, however, a natural way to assess individual bids. We can compare the values of acquired shares using the (ex post) prices on the secondary market after the bidding scheme ended. ${ }^{23}$ In fact, individuals were motivated by the vision of substantial rewards that they could collect in the secondary market instituted by the government. Their bidding strategy was aimed at collecting valuable shares of privatized firms (and to sell them later on the stock market). Thus, under the conditions of our experiment, learning should factor into the course of actions through which individual investors improved over time in terms of the future value of their bids on the stock market.

Therefore, we opt to assess individuals' performance in terms of the acquired shares valued with prices these shares carried on the secondary market after the bidding process ended. In order to have representative and relatively smooth data even for less frequently traded stocks, we use for each share the average price over the three month period April - June 1995. This means that in our valuation we employ the share prices

${ }^{23}$ This approach is in the spirit of Erev and Roth (1998), who study both the ex post ('best fit') descriptive power of learning models, and their ex ante predictive power. 
close to the period after the bulk of shares from the second wave of the voucher scheme entered the market. Also, during this period the majority of trades were initiated by individual sellers, liquidity was relatively high, and, hence, the prices should correspond to the expected payoff for the majority of participants. Further, by choosing this period we do not consider the medium and long run effect on stock prices caused by changes in ownership structure and corporate governance after the end of voucher privatization. Similar to the standard approach in financial literature, we allow for a one-month "settle-down period" and do not consider prices from March 1995, when trading began.

Since individual investors placed their bids in various quantities across rounds, we have to standardize the value of their bids. Clearly, we have to consider the value of shares obtained per one voucher point. In order to homogenize the value of shares offered in each round, we link each round with a particular performance benchmark (defined below). Typical candidates would be weighted averages of values of shares purchased in a particular round. In other words, our benchmarks (mean value or return assigned to each round) will be equal some portfolio value. For our particular experiment, to detect and quantify the hypothesized learning we define measures of learning based on the value of shares achieved per point spent in the bidding. In terms of our experiment, learning is taking place when an individual investor outperforms the benchmark or, for an underperforming individual, the distance from a benchmark is getting smaller over time.

In order to define value per point (bid or spent) we consider the following three kinds of investors: uninformed $(U)$, i.e. an individual investor in our sample, informed $(I)$, i.e. a privatization fund, and market portfolio $(M)$, i.e. passive investor bidding according to market capitalization measured in voucher points (a.k.a. index portfolio). The market portfolio is in fact the value weighted portfolio, similar to the Capital Asset Pricing Model of Sharpe (1964), Lintner (1965), and Mossin (1966). Following Sharpe $(1970$, p. 82), for each separate round of our experiment the market portfolio $(M)$ is defined as the sum of proportions invested in the $i$ firms being privatized $\left(X_{i}^{M}\right)$. Formally, the proportions are defined as 


$$
X_{i}^{M}=\frac{P_{i} Q_{i}}{\sum_{j=1}^{N} P_{j} Q_{j}} \quad \text { for } i=1,2, \ldots, N
$$

where $P_{i}$ represents the price of a share of privatized firm $i$ expressed in voucher points for a particular round where such a price is the result of the bidding mechanism, and $Q_{i}$ represents the number of shares outstanding (e.g. number of shares allocated in each round). Hence, our market portfolio $M$ is defined as

$$
M=\sum_{i=1}^{N} X_{i}^{M}
$$

Note that since, in our experiment, there is no riskless asset (e.g. in our context there is no privatized firm for which a successful bid could be made without risk and with guaranteed return) the market portfolio in our case does not contain such an instrument. Also, our market portfolio is calculated for each round separately so that we can make a dynamic comparison over the rounds. Thus, the market portfolio in our experiment is a collection of share holdings in which the voucher point value of each holding is proportional to the market capitalization of the respective company measured in voucher points.

Let us denote value per point (spent or bid) for uninformed (individual) $j$-th investor in round $t$ as $V_{U}(j, t)$, value per point for informed investor in round $t$ (average value of all informed investors) as $V_{I}(t)$, and value per point for market portfolio in round $t$ as $V_{M}(t)$. Further, we define two measures of performance of an individual in the bidding process in the form of performance distance from two benchmarks: these are performance of the market portfolio and performance of the informed investor.

First, distance of individual relative performance from market portfolio performance is defined as

$$
D_{M}(j, t)=\max \left(1-\frac{V_{U}(j, t)}{V_{M}(t)} ; 0\right) .
$$

Second, analogously, distance of individual relative performance from informed investor performance is defined as 


$$
D_{I}(j, t)=\max \left(1-\frac{V_{U}(j, t)}{V_{I}(t)} ; 0\right) .
$$

For those individuals outperforming the chosen benchmark we set the distance equal to zero and we don't scrutinize the extent of such "outperforming".

In our experiment, observed change due to experience (e.g. learning) means that individual investors perform better over time in the bidding process, i.e., individual performance either exceeds or is getting closer to the selected benchmark. Let us note that even if an individual were to receive a larger value for unit amount of points spent, it does not guarantee that the distance between the benchmark is getting smaller. Mean value of shares offered in each round could increase over time since, as we noted earlier, our experiment is an asymmetric scheme (buying shares in excess supply simply means overpricing). It is expected that yield would increase in higher rounds. Table 5, which contains the values of the market portfolio in each round, confirms such expectations. Note that very high maximum payoffs can be observed in rounds 2-4. This pattern in understandable since in round 1 the prices were set in a uniform pattern based on the book values of the firm; these book values were founded on the accounting principles from the command economy. We conjecture that during later rounds the potential payoff increases dramatically (due to excess demand rule) and corresponds to the high motivation of individuals. Due to the fact that the price setting mechanism is based on an excess demand rule, the prices in later rounds move closer to their equilibrium, and the market portfolio is close to the optimal bidding strategy. The above pattern, in which an excessive rent is vanishing over time and prices converge to equilibrium, conforms with the classical argument in Smith (1962).

In the context of our performance indicators, learning means that performance indicators do not deteriorate over time ${ }^{24}$. Specifically, we formulate our null hypotheses and their alternatives as:

$$
\begin{aligned}
& H_{0}: D_{M}(j, t) \geq D_{M}(j, t+1), \quad H_{A}: D_{M}(j, t)<D_{M}(j, t+1) \\
& H_{0}: D_{I}(j, t) \geq D_{I}(j, t+1), \quad H_{A}: D_{I}(j, t)<D_{I}(j, t+1)
\end{aligned}
$$

\footnotetext{
${ }^{24}$ As mentioned earlier this approach is more restrictive to those individuals performing below the selected benchmark and less restrictive to those that outperform the given benchmark.
} 


\subsection{Statistical inference}

To verify our hypotheses we have essentially two options:

1) One is to estimate a model and compare relevant coefficients. In such a case, we would exploit the dynamic panel structure of our data, assume normality of residuals, and inspect time-varying coefficients between bidding stages, which would be equivalent to conventional $t$-tests. Let us note that a standard panel estimation procedure (involving dynamic structure of the data) typically leads to biased estimates (for an exposition see Wooldridge, 2002). ${ }^{25}$ Moreover, a formal model that would capture the complexity of our experiment could easily be misspecified, which might result in biased coefficients and a less than accurate inference.

2) To detect learning, as it is specified above, we are principally interested in movements of coefficients up and down (increase or decrease in performance) rather than in estimating specific values of such coefficients. Therefore, it is better to use a panel data structure to properly match individual performance between rounds and test whether we observe an improvement in performance. Moreover, we can relax any distribution assumptions and employ a non-parametric approach.

For the above reasons we do not build the model and we use the second option. We chose to verify the postulated hypotheses by conducting a series of sign tests for paired data. It is a robust nonparametric approach that has been used as an alternative to the paired $t$-test for a considerable time (for its introduction see Dixon and Mood, 1946; its detailed property including asymptotic distributions are derived in Hájek and Šidák, 1967). In this approach we treat our data as a panel with fixed effects since when analyzing differences between two rounds, such differences eliminate individual effects as well as bias and heterogeneity of agents. In this way we are able to avoid major problems that plague experimental analysis, namely bias due to heterogeneity of agents (see Wilcox 2003).

${ }^{25}$ Well-known procedures, which account for error dynamics, either require a good set of additional instrumental variables (which we do not have) or are based on application of the Arellano-Bond procedure (see Arellano and Bond, 1991). The Arellano-Bond approach is based on differences of variables, and two lagged variables in levels are employed as valid instruments. We would lose the first two bidding rounds of data if we employed the Arellano-Bond procedure. Hence, neither of the two methods above is a viable option in our case. 
Briefly, given $n$ pairs of data, the sign test tests the hypothesis that the median of the differences in the pairs is zero. The test statistic is the number of positive differences. If the null hypothesis is true, then the numbers of positive and negative differences should be approximately the same. Formally, we take the paired observations, calculate the differences, and count the number of positive signs $n_{+}$and negative signs $n_{-}$, where $N \equiv n_{+}+n_{-}$is the sample size, and then we calculate the binomial coefficient $B \equiv\left(\begin{array}{c}N \\ n_{+}\end{array}\right)$. Then $B / 2^{N}$ gives the probability of getting exactly this many positive signs and negative signs if positive and negative values are equally likely. Finally, to obtain the $p$-value for the test, we sum all the binomial coefficients that are less than or equal to $B$ and divide the sum by $2^{N}$. The number of positive differences will have a binomial distribution with parameters $n$ and $p$. The procedure has been frequently used in the empirical finance literature on stock or exchange rate returns. ${ }^{26}$

The approach outlined above allows us to track the performance of each individual investor over time at each round and compare such performance with that of our two benchmarks. ${ }^{27}$ Rejecting the null hypothesis means that learning is detected.

\subsection{Empirical observations of learning}

By virtue of bidding rules and limited resources (1000 points per individual only) individual investors could not repeat their bids. For this reason any sign of learning detected in our experiment would be lower-bound learning. However, that would mean that if learning is detected, it is a strong indication of learning, indeed.

The condensed results of the sign tests are presented in Tables 6-7. Let us briefly introduce the exposition presented in these tables. Rows $i$ and column $j$ in both tables correspond to rounds $i$ and $j$ in which sub-populations of our sample successfully placed their bids. The numbers presented in this $(i, j)$ intersection correspond to the sign test of the hypothesis that there is no learning effect found between corresponding round $i$ and

\footnotetext{
${ }^{26}$ See Flores (1986); Zivney and Thompson (1989); Corrado and Zivney (1992); Abrevaya (2000); Fatum and Hutchinson (2003), among others.

${ }^{27}$ Thanks to the extensive panel structure of our data we are able to trace learning of individuals across rounds as well.
} 
$j$. To be specific, for example, the first cell in Table 6 contains the following symbols and numbers $\uparrow \mathbf{2 6 1} * *, \downarrow 80$, p-value: 0.001 . This means that there were $341(=261+80)$ individuals which successfully placed their bids between rounds 1 and 2; for 261 individuals the distance between the benchmark (in this case the market portfolio) decreases while for 80 individuals the distance from the benchmark increases; $p$-value of the underlying sign test was lower than 0.001, bold face letters highlight that there was significant increase in relative performance between round 1 and 2 , and finally (**) marks the level of significance (1\%).

It is clear that the diagonal cells of Tables 6-7 present results of sign tests for performance between two successive rounds. As complementary evidence, in the other cells of the upper right triangle of each table we provide results of learning between two non-successive rounds.

When learning is measured with the help of the distance of individual relative performance from market portfolio performance $\left(D_{M}(j, t)\right)$ the evidence of learning between consequent rounds (diagonal cells) is overwhelming. In all cells on the diagonal, learning is detected at the highest significance levels. This we can identify as an instantaneous effect of learning. ${ }^{28}$ Further, the number of individual investors who bid in each round and actually allocated their bids successfully increases up (but not including) to the fourth round.

The evidence of learning as measured by the distance of individual relative performance from informed investor (fund) performance $\left(D_{I}(j, t)\right)$ is shown in Table 7. However, given the different objectives of the privatization funds (mostly control of the companies), institutional barriers (a PIF could control only up to $20 \%$ of the company) and different behavior at the end-of-the-game, we should look primarily at the early rounds. Results between rounds 1 to 3 again show a very convincing pattern of learning. Given this, the results from the fourth round are somewhat puzzling. Clearly, the performance of the PIFs in the last round is due to the end-of-the-game problem given the fact that voucher points after the last round had zero value. Nevertheless, even if we do not adjust for the different objectives of institutional investors (and some

\footnotetext{
${ }^{28}$ Like in Berk, Hughson, and Vandezande (1996), learning during the bidding experiment reduces the frequency of errors and may be interpreted as evidence of bounded rationality.
} 
restrictions) in later rounds, we reject the learning hypothesis only between rounds 4 and 5. This means that we reject learning only in one case out of 5 possible outcomes.

In addition, we also consider a stronger version of learning by analyzing individuals' behavior between two non-consecutive rounds. The relevant hypotheses would be formulated in the following form:

$$
\begin{array}{lll}
H_{0}: D_{M}(j, t) \geq D_{M}(j, t+s), & H_{A}: D_{M}(j, t)<D_{M}(j, t+s), & s>1 \\
H_{0}: D_{I}(j, t) \geq D_{I}(j, t+s), \quad H_{A}: D_{I}(j, t)<D_{I}(j, t+s), & s>1
\end{array}
$$

In fact, in hypotheses (7) and (8) we ask to what extent learning has a long-term effect. As we can see from Table 6, in none of the possible cases were we able to reject hypothesis (7). Moreover, eight out of ten possible tests show significant effects of learning even in the case of a bigger time distance between compared rounds. Likewise for hypothesis (8), we observe evidence of learning; 7 out of 10 possible tests produce significant effects. This result is strengthened by the fact that there was not a single case in which we would be able to reject the long-term effect of learning.

Our results are in line with the findings of List (2004c), who concludes that "market experience plays a role in the distribution of rents: experienced market players earn more rents than inexperienced agents." Further, the design of our experiment contains multiple market periods that allow agents to learn based on their accumulated experience. We have shown that learning occurred in between successive as well as non-successive auction stages. In this context, our results lend a new perspective to the findings of Smith (1962) and List (2004c).

\section{Conclusion}

In this paper, we have tested for learning among relatively uninformed heterogeneous individuals engaged in bidding on a proxy stock market. We have used an extensive natural experiment - the voucher scheme of the (1993-1994) privatization in the Czech Republic - to avoid shortcomings of laboratory experiments. Towards this end, we developed new measures of individual performance to accommodate for varying prices of goods (shares) available in six successive stages of bidding. 
Specifically, we have used the equivalent of a market portfolio as a benchmark and we have scaled performance of individual investors to this benchmark. Since the benchmark increases over time, an individual investor learns if s/he performs better than the benchmark. In a similarly, we adopted a second benchmark, the fund portfolio. We performed all possible pair-matched sign tests. In none of the sign tests were we able to reject the learning hypothesis, with the single exception of a performance difference between the fourth and fifth bidding stage when benchmarked to institutional investors. This means that only one out of thirty possible pair-wise tests rejected the learning effect (i.e., less than $3.3 \%$ of all possible tests), while seven tests do not reject our hypotheses and twenty two show a significant effect of learning.

Our paper supplements the theoretical literature on learning by bringing convincing evidence of the learning that took place during the auction-like process. We have used a large dataset from a natural experiment that by size, incentives, and variation is superior to any laboratory experiment we know of. Since individuals had to pay a fee to participate, and the potential gain was in the magnitude of several months' salary, we believe that large incentives were driving our results. 


\section{Appendix}

Following Aggarwal and Harper (2000), the Czech privatization auction can be formally described by the following rules:

1. There are $M$ firms with $N$ shares of each firm for a total of $M \times N$ shares in the auction. These shares are offered in rounds $r(r=1 \ldots i)$. The number of shares offered in each round is $S_{m, r}\left(S_{m, 1}=N_{m, 1}\right)$ at price $p_{m, r}$. In the first round, all prices (but not book value) are equal for all firms. At the beginning of each round, orders are taken for each firm at price $p_{m, r}$ and number of shares $n_{m, r}$. The sum of shares ordered from all inventors in each round for each firm is given by:

$D_{m, r}=\sum_{n=1}^{N} n_{m, r}$

2. The number of vouchers is known and no new coupons enter the auction after the first round has begun.

3. Trading occurs when the following condition holds:

$\alpha S_{m, r}<D_{m, r}<\gamma S_{m, r}, \alpha<1$ and $\gamma>1$

$\alpha<\frac{D_{m, r}}{S_{m, r}}<\gamma$, remaining shares, $S_{m, r}-D_{m, r}$, proceed to next round.

If demand is lower than the boundary condition, $D_{m, r}<\alpha S_{m, r}$, then no shares are sold and the price is lowered for the next round, $p_{m, r}+1=f\left(\alpha S_{m, r} / D_{m, r}\right)$. If demand is greater than supply, then no shares are sold and the price is raised for the next round. That is if $D_{m, r}>\not S_{m, r}$, then $p_{m, r}=f\left(\not S_{m, r} / D_{m, r}\right)$. If $S_{m, r}<D_{m, r}<\gamma S_{m, r}$, then shares are prorated. $\alpha$ and $\gamma$ are constant, but are not known initially. The equilibrium price is $D_{m} / S_{m}=1$. After the auction began, these boundary conditions remained constant and were known to be $\alpha=0$ and $\gamma=1.25$. 


\section{References}

Abrevaya, Jason. 2000. Testing for a Treatment Effect in a Heterogeneous Population: A Modified Sign-Test Statistic and a Leapfrog Statistic. Journal of Applied Statistics. 27(6): 679-87.

Aggarwal, Raj, and Joel T. Harper. 2000. Equity Valuation in the Czech Voucher Privatization Auctions. Financial Management, 29(4): 77-100.

Arellano, Manuel and Bond, Stephen. 1991. Some Tests of Specification for Panel Data: MonteCarlo Evidence and an Application to Employment Equations, Review of Economic Studies, 58(2), 277-297.

Berk, Jonathan, Hughson, Eric, and Vandezande, Kirk. 1996. The Price Is Right, but Are the Bids? An Investigation of Rational Decision Theory. American Economic Review, 86(4): 954-70.

Camerer, Colin F. 2003. Behavioral Game Theory: Experiments in Strategic Interaction. Princeton University Press, Princeton, New Jersey.

Camerer, Colin F, and Teck Ho. 1999. Experience-weighted attraction learning in games: Estimates from weak-link games. In D. Budescu, I. Erev, and R. Zwick (Eds.), Games and Human Behavior: Essays in Honor of Amnon Rapoport. Mahwah, N.J.: Lawrence Erlbaum.

Carbone, E. 2004. "The Effect of Unemployment on Saving: An Experimental Analysis with Panel Subjects," University of New York, Working Paper.

Corrado, Charles J. and Zivney, Terry L. 1992. The Specification and Power of the Sign Test in Event Study Hypothesis Tests Using Daily Stock Returns. Journal of Financial and Quantitative Analysis. 27(3): 465-78.

Dixon, W.J. and Mood, A.M. 1946. "The statistical sign test," Journal of American Statistical Association, 41, 557-566.

Erev, Ido and Roth, Alvin E. 1998. Predicting How People Play Games: Reinforcement Learning in Experimental Games with Unique, Mixed Strategy Equilibria. American Economic Review, 88(4): 848-81

Fatum, Rasmus and Hutchison, Michael M. 2003. Is Sterilised Foreign Exchange Intervention Effective after All? An Event Study Approach. Economic Journal. 113(487): 390-411.

Filer, R.K. and Hanousek, J. 2001."Efficiency of Price Setting Based on a Simple Excess Demand Rule: The Natural Experiment of Czech Voucher Privatization," European Economic Review, 45: 9, 1619-1646. 
Flores, Benito E. 1986. Use of the Sign Test to Supplement the Percentage Better Statistic. International Journal of Forecasting. 2(4): 477-89.

Friedman, Daniel, Harrison, Glenn W., Salmon, Jon W. 1984. The Informational Efficiency of Experimental Asset Markets. Journal of Political Economy, 92(3): 349-408.

Fudenberg, Drew and David Levine. 1998. The Theory of Learning in Games. MIT Press, Cambridge, Massachusetts.

Hájek, Jaroslav and Šidák, Zbyněk. 1967. The Theory of Rank Test. Academic Press, New York and Academia, Prague.

Hanousek, Jan and Eugene A. Kroch. 1998. "The Two Waves of Voucher Privatization in the Czech Republic: A Model of Learning in Sequential Bidding," Applied Economics, 30: 133-143.

Harrison, Glenn W. 1989. Theory and Misbehavior of First-Price Auctions. American Economic Review, 79(4): 749-62

Harrison, Glenn W., Lau, M. I, and Williams, M.B. 2002. "Estimating Individual Discount Rates in Denmark: A Field Experiment." American Economic Review, 92(5), 1606-17.

Harrison, Glenn W. and John A. List. 2003. "Naturally Occurring Markets and Exogenous Laboratory Experiments: A Case Study of the Winner's Curse." University of Central Florida Working Paper.

Harrison, Glenn W. and John A. List. 2004. "Field Experiments." Journal of Economic Literature, 42(4): 1009-1055.

Harrison, Glenn W., Lau, M. I., Rutström, E. E. and Sullivan, M. B. 2005. "Eliciting Risk and Time Preferences Using Field Experiments: Some Methodological Issues." In J. Carpenter, G.W. Harrison and J.A. List (eds.), Field Experiments in Economics, Research in Experimental Economics, Volume 10, Greenwich, CT: JAI Press.

Hertwig, R. and A. Ortmann: Experimental practices in economics: a methodological challenge for psychologists?, Behavioral and Brain Sciences 24, 383-451, 2001.

Holt, Charles A and Laury, Susan K. 2002. Risk Aversion and Incentive Effects. American Economic Review, 92(5): 1644-55. 
Hung, Angela A. and Charles R Plott. 2001. Information Cascades: Replication and an Extension to Majority Rule and Conformity-Rewarding Institutions. American Economic Review, 91(5): 1508-20

Kachelmeier, Steven J., Shehata, Mohamed. 1992. Examining Risk Preferences under High Monetary Incentives: Experimental Evidence from the People's Republic of China. American Economic Review, 82(5): 1120-41

Kagel, John H. and Alvin E. Roth. 1997, The Handbook of Experimental Economics, Princeton University Press.

Kočenda, Evžen. 1999. Residual State Property in the Czech Republic, Eastern European Economics, Vol. 37(5), pp. 6-35.

Kotrba, Josef. 1995. Privatization Process in the Czech Republic: Players and Winners, pp. 159-198. In Svejnar, J., The Czech Republic and Economic Transition in Eastern Europe. San Diego; London and Toronto: Harcourt Brace, Academic Press.

Kotrba J., Kočenda, E., and Hanousek, J. 1999. The Governance of Privatization Funds in the Czech Republic, 7-43. In: Simoneti, M., Estrin, S., and Boehm, A. (eds.), The Governance of Privatization Funds: Experiences of the Czech Republic, Poland and Slovenia. Edward Elgar, London, 1999.

Lintner, J. 1965. The valuation of risk assets and the selection of risky investment in stock portfolios and capital budgets. Review of Economics and Statistics 47: 1337.

List, John A. 2003. Does Market Experience Eliminate Market Anomalies?, Quarterly Journal of Economics,118(1), pp. 41-71.

List, John A. 2004a. Young, Selfish, and Male: Field Evidence of Social Preferences, Economic Journal, 114(492): pp. 121-149.

List, John A. 2004b. The Nature and Extent of Discrimination in the Marketplace: Evidence from the Field, Quarterly Journal of Economics, 119(1): pp. 49-89.

List, John A. 2004c. Testing Neoclassical Competitive Theory in Multilateral Decentralized Markets, Journal of Political Economy, 112(5): 1131-1156

Mosin, J. 1966. Equilibrium in a capital asset market. Econometrica 34: 768-783.

Sharpe, W. 1964. Capital asset prices: A theory of capital market equilibrium under condition of risk. Journal of Finance 19: 425-442.

Sharpe, W. 1970. Portfolio Theory and Capital Markets. McGraw-Hill, New York. 
Slonim, Robert and Roth, Alvin E. 1998. Learning in High Stakes Ultimatum Games: An Experiment in the Slovak Republic. Econometrica, 66(3): 569-96.

Smith, Vernon L. 1962. An Experimental Study of Competitive Market Behavior, Journal of Political Economy, 70(2), pp. 111-137.

Smith, Vernon L., 1976, Experimental economics: induced value theory, American Economic Review Proceedings 66, 247-279.

Smith, Vernon L., 1982, Microeconomic systems as an experimental science, American Economic Review 72, 923-955

Smith, Vernon L. and J. Walker 1993: Monetary rewards and decision cost in experimental economics, Economic Inquiry 31, 245-261.

Suppes P., and Atkinson R. C. 1960. Markov learning models for multi person interactions. Stanford: Stanford University Press.

Valbonesi, P., 1995. "Privatizing by Auction in the Eastern European Transition Countries: The Czechoslovak experience," MOCT-MOST, 5, 101-131.

Vega-Redondo, F. 2003. Economics and the theory of games. Cambridge, UK: Cambridge University Press.

Weibull, Jörgen. 1995. Evolutionary Game Theory. MIT Press, Cambridge, Massachusetts.

Wilcox, N. 1993. Lottery choice: incentives, complexity, and decision time, The Economic Journal 103, 1397-1417.

Wilcox, N. 2003. Heterogeneity and learning principles, University of Houston Department of Economics Working Paper.

Wooldridge, Jeffrey M. 2002. Econometric Analysis of Cross Section and Panel Data. MIT Press, Cambridge, Massachusetts.

Zivney, Terry L. and Thompson, Donald J. 1989. The Specification and Power of the Sign Test in Measuring Security Price Performance: Comments and Analysis. Financial Review. 24(4): 581-88. 
Table 1. Voucher Privatization - Time Framework

\begin{tabular}{|l|l|}
\hline \multicolumn{1}{|c|}{ Steps in Voucher Scheme } & \multicolumn{1}{c|}{ Second Wave } \\
\hline Preparation & January-September 1993 \\
Voucher Book issue & since October 1993 \\
Registration & October - December 1993 \\
0-round & December 1993 - March 1994 \\
Vouchers to Funds) & April - December 1994 \\
1st-6th Round & December 31, 1994 \\
Official End & February 1995 \\
Transfer of Shares & March 1995 \\
Trading of Shares Started & April 1995 \\
First PIF Shares Issued & \\
\hline \hline
\end{tabular}

Source: Ministry of Privatization. 
Table 2. Points available

\begin{tabular}{|r|r|r|r|r|r|r|r|}
\hline \hline \multicolumn{7}{|c|}{ A. Distributions: Points available } \\
\hline Variable & Round 1 & Round 2 & Round 3 & Round 4 & Round 5 & Round 6 & The end \\
\hline \multicolumn{7}{|c|}{ Points distribution } \\
\hline 0 & & $5.4 \%$ & $17.4 \%$ & $30.3 \%$ & $62.6 \%$ & $78.7 \%$ & $88.8 \%$ \\
\hline 100 & & $0.0 \%$ & $0.8 \%$ & $1.6 \%$ & $3.0 \%$ & $3.6 \%$ & $2.2 \%$ \\
\hline 200 & & $0.3 \%$ & $2.2 \%$ & $3.9 \%$ & $6.8 \%$ & $5.1 \%$ & $1.8 \%$ \\
\hline 300 & & $0.2 \%$ & $1.0 \%$ & $2.2 \%$ & $2.7 \%$ & $2.0 \%$ & $1.7 \%$ \\
\hline 400 & & $1.0 \%$ & $3.2 \%$ & $6.5 \%$ & $5.3 \%$ & $2.7 \%$ & $1.6 \%$ \\
\hline 500 & & $6.6 \%$ & $10.2 \%$ & $10.7 \%$ & $5.5 \%$ & $2.6 \%$ & $1.1 \%$ \\
\hline 600 & & $2.3 \%$ & $4.5 \%$ & $6.6 \%$ & $2.5 \%$ & $1.1 \%$ & $0.6 \%$ \\
\hline 700 & & $1.1 \%$ & $1.6 \%$ & $2.2 \%$ & $0.7 \%$ & $0.4 \%$ & $0.4 \%$ \\
\hline 800 & & $5.4 \%$ & $6.5 \%$ & $5.6 \%$ & $1.2 \%$ & $0.6 \%$ & $0.6 \%$ \\
\hline 900 & & $1.2 \%$ & $1.3 \%$ & $1.1 \%$ & $0.5 \%$ & $0.7 \%$ & $0.8 \%$ \\
\hline 1000 & $100.0 \%$ & $76.5 \%$ & $51.3 \%$ & $29.4 \%$ & $9.2 \%$ & $2.7 \%$ & $0.5 \%$ \\
\hline \multicolumn{7}{|c|}{ Descriptive statistics } \\
\hline mean & 1000 & 879 & 687 & 499 & 199 & 90 & 46 \\
\hline std. dev. & 0 & 264 & 387 & 406 & 323 & 221 & 158 \\
\hline \multicolumn{7}{|c|}{ B. People who did not bid till certain round } \\
\hline Variable & Round 1 & Round 2 & Round 3 & Round 4 & Round 5 & Round 6 & The end \\
\hline Not bid & 1009 & 307 & 100 & 64 & 23 & 0 & -- \\
\hline \hline
\end{tabular}

Sample size: 5000 individuals.

Note: In the first round all individuals have 1000 points available. Since every individual could allocate the voucher points only in multiples of hundreds, the table above gives detailed distribution of points available at the beginning of each round (this information can be used to construct a similar distribution of the points spent). The fact that $x \%$ of participants have $y$ points available in the second round means that $x \%$ of participants spent their (1000-y) points in the first round. A similar decomposition could be used for later rounds. 
Table 3. Points bid

\begin{tabular}{|r|r|r|r|r|r|r|}
\hline \hline \multicolumn{7}{|c|}{ A. Distributions: Points bid } \\
\hline Variable & Round 1 & Round 2 & Round 3 & Round 4 & Round 5 & Round 6 \\
\hline \multicolumn{7}{|c|}{ Points distribution } \\
\hline 0 & $20.2 \%$ & $17.9 \%$ & $25.1 \%$ & $40.9 \%$ & $69.4 \%$ & $85.5 \%$ \\
\hline 100 & $0.1 \%$ & $0.0 \%$ & $1.4 \%$ & $1.9 \%$ & $3.1 \%$ & $3.0 \%$ \\
\hline 200 & $0.1 \%$ & $0.3 \%$ & $2.4 \%$ & $3.6 \%$ & $6.4 \%$ & $4.6 \%$ \\
\hline 300 & $0.1 \%$ & $0.3 \%$ & $1.2 \%$ & $2.0 \%$ & $1.7 \%$ & $0.7 \%$ \\
\hline 400 & $0.2 \%$ & $1.1 \%$ & $3.2 \%$ & $5.3 \%$ & $4.1 \%$ & $1.6 \%$ \\
\hline 500 & $1.1 \%$ & $7.0 \%$ & $8.9 \%$ & $8.4 \%$ & $3.9 \%$ & $1.4 \%$ \\
\hline 600 & $0.6 \%$ & $2.6 \%$ & $4.6 \%$ & $6.3 \%$ & $2.3 \%$ & $0.7 \%$ \\
\hline 700 & $0.1 \%$ & $1.2 \%$ & $1.3 \%$ & $1.5 \%$ & $0.3 \%$ & $0.1 \%$ \\
\hline 800 & $0.7 \%$ & $5.4 \%$ & $6.1 \%$ & $5.4 \%$ & $1.0 \%$ & $0.1 \%$ \\
\hline 900 & $0.2 \%$ & $1.2 \%$ & $1.1 \%$ & $0.6 \%$ & $0.0 \%$ & $0.0 \%$ \\
\hline 1000 & $76.6 \%$ & $62.8 \%$ & $44.7 \%$ & $24.3 \%$ & $7.7 \%$ & $2.2 \%$ \\
\hline \multicolumn{7}{|c|}{ Descriptive statistics } \\
\hline mean & 785 & 749 & 612 & 418 & 159 & 57 \\
\hline std. dev. & 403 & 387 & 422 & 414 & 300 & 184 \\
\hline
\end{tabular}

B. Distributions: Points bid (for those who had at least 100 points)

\begin{tabular}{|r|r|r|r|r|r|r|}
\hline Variable & Round 1 & Round 2 & Round 3 & Round 4 & Round 5 & Round 6 \\
\hline \multicolumn{7}{|c|}{ Points distribution } \\
\hline 0 & $20.2 \%$ & $13.3 \%$ & $9.4 \%$ & $15.4 \%$ & $18.7 \%$ & $32.6 \%$ \\
\hline 100 & $0.1 \%$ & $0.0 \%$ & $1.7 \%$ & $2.7 \%$ & $8.3 \%$ & $14.1 \%$ \\
\hline 200 & $0.1 \%$ & $0.4 \%$ & $2.9 \%$ & $5.2 \%$ & $17.0 \%$ & $21.5 \%$ \\
\hline 300 & $0.1 \%$ & $0.3 \%$ & $1.5 \%$ & $2.9 \%$ & $4.6 \%$ & $3.4 \%$ \\
\hline 400 & $0.2 \%$ & $1.2 \%$ & $3.9 \%$ & $7.6 \%$ & $11.0 \%$ & $7.3 \%$ \\
\hline 500 & $1.1 \%$ & $7.4 \%$ & $10.8 \%$ & $12.0 \%$ & $10.3 \%$ & $6.7 \%$ \\
\hline 600 & $0.6 \%$ & $2.7 \%$ & $5.6 \%$ & $9.0 \%$ & $6.2 \%$ & $3.1 \%$ \\
\hline 700 & $0.1 \%$ & $1.3 \%$ & $1.6 \%$ & $2.1 \%$ & $0.7 \%$ & $0.7 \%$ \\
\hline 800 & $0.7 \%$ & $5.8 \%$ & $7.4 \%$ & $7.7 \%$ & $2.7 \%$ & $0.6 \%$ \\
\hline 900 & $0.2 \%$ & $1.3 \%$ & $1.4 \%$ & $0.8 \%$ & $0.1 \%$ & $0.2 \%$ \\
\hline 1000 & $76.6 \%$ & $66.4 \%$ & $54.0 \%$ & $34.7 \%$ & $20.3 \%$ & $9.9 \%$ \\
\hline \multicolumn{7}{|c|}{ Descriptive statistics } \\
\hline mean & 785 & 790 & 737 & 597 & 420 & 258 \\
\hline std. dev. & 403 & 352 & 344 & 370 & 355 & 305 \\
\hline \hline
\end{tabular}

Sample size: 5000 individuals.

Note: Participants of the bidding scheme could allocate their vouchers only in multiples of hundreds; therefore, the table above provides detailed information on bidding patterns. Since individuals spent their points across rounds, their available points differ significantly since the second round. To account for points already spent we present both distributions. The upper part of Table (A) depicts a regular bidding pattern (unconditional distribution), while the lower part of Table (B) contains a conditional distribution of bidding for those individuals that have at least 100 available points. 
Table 4. Points spent

\begin{tabular}{|c|c|c|c|c|c|c|}
\hline \multicolumn{7}{|c|}{ A. Distributions: Points spent } \\
\hline Variable & Round 1 & Round 2 & Round 3 & Round 4 & Round 5 & Round 6 \\
\hline \multicolumn{7}{|c|}{ Points distribution } \\
\hline 0 & $76.5 \%$ & $68.0 \%$ & $63.5 \%$ & $50.1 \%$ & $75.4 \%$ & $87.2 \%$ \\
\hline 100 & $1.2 \%$ & $1.3 \%$ & $2.5 \%$ & $2.1 \%$ & $3.3 \%$ & $3.0 \%$ \\
\hline 200 & $5.4 \%$ & $5.2 \%$ & $7.3 \%$ & $5.4 \%$ & $5.9 \%$ & $4.2 \%$ \\
\hline 300 & $1.1 \%$ & $1.1 \%$ & $2.1 \%$ & $2.5 \%$ & $2.1 \%$ & $0.9 \%$ \\
\hline 400 & $2.3 \%$ & $3.7 \%$ & $5.5 \%$ & $7.8 \%$ & $3.8 \%$ & $1.2 \%$ \\
\hline 500 & $6.6 \%$ & $6.2 \%$ & $6.2 \%$ & $7.8 \%$ & $2.9 \%$ & $1.2 \%$ \\
\hline 600 & $1.0 \%$ & $2.1 \%$ & $3.2 \%$ & $5.6 \%$ & $1.4 \%$ & $0.5 \%$ \\
\hline 700 & $0.2 \%$ & $0.6 \%$ & $0.7 \%$ & $1.2 \%$ & $0.3 \%$ & $0.1 \%$ \\
\hline 800 & $0.3 \%$ & $1.6 \%$ & $1.2 \%$ & $3.2 \%$ & $0.9 \%$ & $0.3 \%$ \\
\hline 900 & $0.0 \%$ & $0.6 \%$ & $0.4 \%$ & $0.4 \%$ & $0.1 \%$ & $0.2 \%$ \\
\hline 1000 & $5.4 \%$ & $9.5 \%$ & $7.3 \%$ & $13.8 \%$ & $3.9 \%$ & $1.2 \%$ \\
\hline \multicolumn{7}{|c|}{ Descriptive statistics } \\
\hline mean & 121 & 192 & 188 & 300 & 109 & 44 \\
\hline std. dev. & 264 & 330 & 306 & 367 & 242 & 152 \\
\hline \multicolumn{7}{|c|}{ B. Distributions: Points spent (for those who had at least 100 points) } \\
\hline Variable & Round 1 & Round 2 & Round 3 & Round 4 & Round 5 & Round 6 \\
\hline \multicolumn{7}{|c|}{ Points distribution } \\
\hline 0 & $76.5 \%$ & $66.1 \%$ & $55.9 \%$ & $28.5 \%$ & $34.1 \%$ & $40.1 \%$ \\
\hline 100 & $1.2 \%$ & $1.4 \%$ & $3.0 \%$ & $3.1 \%$ & $8.8 \%$ & $14.2 \%$ \\
\hline 200 & $5.4 \%$ & $5.5 \%$ & $8.9 \%$ & $7.8 \%$ & $15.9 \%$ & $19.5 \%$ \\
\hline 300 & $1.1 \%$ & $1.2 \%$ & $2.6 \%$ & $3.6 \%$ & $5.6 \%$ & $4.3 \%$ \\
\hline 400 & $2.3 \%$ & $4.0 \%$ & $6.6 \%$ & $11.2 \%$ & $10.1 \%$ & $5.5 \%$ \\
\hline 500 & $6.6 \%$ & $6.6 \%$ & $7.5 \%$ & $11.2 \%$ & $7.7 \%$ & $5.6 \%$ \\
\hline 600 & $1.0 \%$ & $2.3 \%$ & $3.9 \%$ & $8.1 \%$ & $3.9 \%$ & $2.5 \%$ \\
\hline 700 & $0.2 \%$ & $0.6 \%$ & $0.9 \%$ & $1.7 \%$ & $0.9 \%$ & $0.7 \%$ \\
\hline 800 & $0.3 \%$ & $1.7 \%$ & $1.5 \%$ & $4.6 \%$ & $2.4 \%$ & $1.3 \%$ \\
\hline 900 & $0.0 \%$ & $0.7 \%$ & $0.5 \%$ & $0.6 \%$ & $0.2 \%$ & $0.8 \%$ \\
\hline 1000 & $5.4 \%$ & $10.1 \%$ & $8.9 \%$ & $19.8 \%$ & $10.5 \%$ & $5.5 \%$ \\
\hline \multicolumn{7}{|c|}{ Descriptive statistics } \\
\hline mean & 121 & 203 & 227 & 430 & 292 & 209 \\
\hline std. dev. & 264 & 337 & 323 & 370 & 321 & 273 \\
\hline
\end{tabular}

Sample size: 5000 individuals.

Note: Participants of the bidding scheme could allocate their vouchers only in multiples of hundreds; therefore, the table above provides detailed information on patterns related to the points spent. The upper part of Table (A) depicts the distribution of points spent at the beginning of each round (this part of the table can be easily derived from Table 1, which shows the distributions of points available). Since individuals spent their points across rounds, their available points differ significantly since the second round. To account for points already spent we present both distributions. The upper part of Table (A) depicts the pattern of points spent (unconditional distribution), while the lower part of Table (B) contains the conditional distribution of points spent for those individuals that have at least 100 available points. 
Table 5. Descriptive statistics -- Performance of Portfolios in CZK per 1 point

\begin{tabular}{|c|c|c|c|c|c|}
\hline \hline \multirow{2}{*}{ Round } & $\begin{array}{c}\text { Market } \\
\text { portfolio }\end{array}$ & $\begin{array}{c}\text { Informed } \\
\text { investor } \\
\text { portfolio }\end{array}$ & \multicolumn{3}{|c|}{ Individuals } \\
\cline { 2 - 6 } & mean & mean & mean & maximum & $\begin{array}{c}95 \% \text { confidence } \\
\text { interval }\end{array}$ \\
\hline 1 & 4.285 & 8.013 & 7.330 & 25.149 & $(7,070 ; 7,590)$ \\
\hline 2 & 6.514 & 12.514 & 15.043 & 313.010 & $(13,535 ; 16,551)$ \\
\hline 3 & 6.060 & 7.895 & 10.543 & 227.540 & $(9,717 ; 11,369)$ \\
\hline 4 & 7.384 & 9.418 & 7.522 & 126.400 & $(7,304 ; 7,739)$ \\
\hline 5 & 10.077 & 11.416 & 10.307 & 55.897 & $(10,047 ; 10,566)$ \\
\hline 6 & 14.048 & 17.312 & 13.463 & 34.337 & $(12,958 ; 13,969)$ \\
\hline \hline
\end{tabular}

Sample size: 5000 individuals

CZK is the abbreviation for the Czech currency unit.

Note: In each bidding round the market portfolio has been constructed as an index portfolio (see equations (1)-(2)), while the informed investor portfolio represents an aggregated portfolio of all privatization investment funds (PIF) that acquired shares in a given round.

Values of portfolios presented in this table are valued at prices on the secondary market after the natural experiment ended. In order to account for less frequently traded stocks, we use for each share the average price over the three month period April - June 1995. This means that in our valuation we employ the share prices close to the period after the bulk of shares from our natural experiment (the second wave of the voucher scheme) entered the market (March 1995), allowing for a one-month "settle-down period".

For ease of comparison the values of all portfolios are measured in CZK per 1 point. Since all participants have 1000 points available, the mean payoffs of individuals (and their counterparts) are obtained by multiplying by 1000 . Very high maximum payoffs can be observed in rounds $2-4$. Since in round 1 the prices were set uniformly in an artificial pattern, we conjecture that during later rounds the potential payoff increases dramatically and corresponds to the high motivation of individuals. Due to the fact that the price setting mechanism is based on an excess demand rule, the prices in later rounds move closer to their equilibrium, and the market portfolio is close to the optimal bidding strategy. 
Table 6. Summary of tests of learning in future rounds. Benchmark is performance (distance) with respect to the market portfolio in each round.

\begin{tabular}{|c|c|c|c|c|c|}
\hline & Round 2 & Round 3 & Round 4 & Round 5 & Round 6 \\
\hline Round 1 & $\begin{array}{l}\uparrow \mathbf{2 6 1} * * \\
\downarrow 80 \\
\text { p-value: } \\
0.001\end{array}$ & $\begin{array}{l}\uparrow \mathbf{2 6 7} * * \\
\downarrow 94 \\
\text { p-value: } \\
0.001\end{array}$ & $\begin{array}{l}\uparrow \mathbf{2 8 4} * * \\
\downarrow 206 \\
\text { p-value: } \\
0.001\end{array}$ & $\begin{array}{l}\uparrow \mathbf{1 3 5} * * \\
\downarrow 78 \\
\text { p-value: } \\
0.001\end{array}$ & $\begin{array}{l}\uparrow 56 \\
\downarrow 44 \\
\text { p-value: } \\
0.136\end{array}$ \\
\hline Round 2 & & $\begin{array}{l}\uparrow \mathbf{3 5 4} \text { ** } \\
\downarrow 127 \\
\text { p-value: } \\
0.001\end{array}$ & $\begin{array}{l}\uparrow \mathbf{3 3 0} * * \\
\downarrow 237 \\
\text { p-value: } \\
0.001\end{array}$ & $\begin{array}{l}\uparrow \mathbf{1 7 0} * * \\
\downarrow 96 \\
\text { p-value: } \\
0.001\end{array}$ & $\begin{array}{l}\uparrow 65 \\
\downarrow 70 \\
\text { p-value: } \\
0.697\end{array}$ \\
\hline Round 3 & & & $\begin{array}{l}\uparrow \mathbf{5 0 3} * * \\
\downarrow 390 \\
\text { p-value: } \\
0.001\end{array}$ & $\begin{array}{l}\uparrow \mathbf{2 4 8} * * \\
\downarrow 157 \\
\text { p-value: } \\
0.001\end{array}$ & $\begin{array}{l}\uparrow \mathbf{1 0 4} * \\
\downarrow 76 \\
\text { p-value: } \\
0.022\end{array}$ \\
\hline Round 4 & & & & $\begin{array}{l}\uparrow \mathbf{3 9 8} * * \\
\downarrow 206 \\
\text { p-value: } \\
0.001\end{array}$ & $\begin{array}{l}\uparrow \mathbf{1 6 3} \text { *** } \\
\downarrow 111 \\
\text { p-value: } \\
0.001\end{array}$ \\
\hline Round 5 & & & & & $\begin{array}{l}\uparrow \mathbf{1 8 0} \text { *** } \\
\downarrow 127 \\
\text { p-value: } \\
0.002\end{array}$ \\
\hline
\end{tabular}

$\uparrow$ denotes learning, $\downarrow$ no learning observed (opposite). Below we list p-value of the sign test.

$*$ and $* *$ denotes $5 \%$ and $1 \%$ significance level, respectively.

Total sample size: 5000 individuals

Note: Rows $i$ and column $j$ in this table correspond to rounds $i$ and $j$ in which sub-populations of our sample placed their bids. The numbers presented in this $(i, j)$ intersection correspond to the sign test of the hypothesis that there is no learning effect found between corresponding round $i$ and $j$. For example, the first cell contains the following symbols and numbers $\uparrow \mathbf{2 6 1} * *, \downarrow 80, \mathrm{p}$-value: 0.001 . This means that there were $341(=261+80)$ individuals who successfully placed their bids between rounds 1 and 2; for 261 individuals the distance between the benchmark (the market portfolio) decreases while for 80 individuals the distance from the benchmark increases; p-value of the underlying sign test was lower than 0.001, bold face letters highlight that there was significant increase in relative performance between rounds 1 and 2 , and finally $(* *)$ marks the level of significance $(1 \%)$. 
Table 7. Summary of tests of learning in future rounds. Benchmark is performance (distance) with respect to the informed investor (PIF) portfolio in each round.

\begin{tabular}{|c|c|c|c|c|c|}
\hline & \begin{tabular}{|l} 
Round 2 \\
\end{tabular} & \begin{tabular}{|l} 
Round 3 \\
\end{tabular} & Round 4 & Round 5 & Round 6 \\
\hline Round 1 & $\begin{array}{l}\uparrow \mathbf{1 8 7} * \\
\downarrow 154 \\
\text { p-value: } \\
0.042 \\
\end{array}$ & $\begin{array}{l}\uparrow \mathbf{2 5 4} * * \\
\downarrow 107 \\
\text { p-value: } \\
0.001\end{array}$ & $\begin{array}{l}\uparrow 231 \\
\downarrow 259 \\
\text { p-value: } \\
0.905\end{array}$ & $\begin{array}{l}\uparrow \mathbf{1 3 2} * * \\
\downarrow 81 \\
\text { p-value: } \\
0.001\end{array}$ & $\begin{array}{l}\uparrow \mathbf{5 6} \\
\downarrow 44 \\
\text { p-value: } \\
0.136\end{array}$ \\
\hline Round 2 & & $\begin{array}{l}\uparrow \mathbf{3 4 4} \text { ** } \\
\downarrow 137 \\
\text { p-value: } \\
0.001\end{array}$ & $\begin{array}{l}\uparrow \mathbf{2 8 9} \\
\downarrow 278 \\
\text { p-value: } \\
0.337\end{array}$ & $\begin{array}{l}\uparrow \mathbf{1 7 8} * * \\
\downarrow 88 \\
\text { p-value: } \\
0.001\end{array}$ & $\begin{array}{l}\uparrow 76 \\
\downarrow 59 \\
\text { p-value: } \\
0.084\end{array}$ \\
\hline Round 3 & & & $\begin{array}{l}\uparrow 328 \\
\downarrow \mathbf{5 6 5} * * \\
\text { p-value: } \\
1.000\end{array}$ & $\begin{array}{l}\uparrow 200 \\
\downarrow 205 \\
\text { p-value: } \\
0.617\end{array}$ & $\begin{array}{l}\uparrow \mathbf{9 1} \\
\downarrow 89 \\
\text { p-value: } \\
0.470\end{array}$ \\
\hline Round 4 & & & & $\begin{array}{l}\uparrow \mathbf{3 9 1} * * \\
\downarrow 213 \\
\mathrm{p} \text {-value: } \\
0.001\end{array}$ & $\begin{array}{l}\uparrow 151 \\
\downarrow 123 \\
\text { p-value: } \\
0.051\end{array}$ \\
\hline Round 5 & & & & & $\begin{array}{l}\uparrow 151 \\
\downarrow 156 \\
\text { p-value: } \\
0.634\end{array}$ \\
\hline
\end{tabular}

$\uparrow$ denotes learning, $\downarrow$ no learning observed (opposite). Below we list p-value of the sign test.

$*$ and $* *$ denotes $5 \%$ and $1 \%$ significance level, respectively.

Total sample size: 5000 individuals

Note: Rows $i$ and column $j$ in this table correspond to rounds $i$ and $j$ in which sub-populations of our sample placed their bids. The numbers presented in this $(i, j)$ intersection correspond to the sign test of the hypothesis that there is no learning effect found between corresponding round $i$ and $j$. For example, the first cell contains the following symbols and numbers $\uparrow 187 * *, \downarrow 154$, p-value: 0.042 . This means that there were $341(=187+154)$ individuals who successfully placed their bids between rounds 1 and 2 ; for 187 individuals the distance between the benchmark (informed investor portfolio) decreases while for 154 individuals the distance from the benchmark increases; $p$-value of the underlying sign test was lower than 0.05 , bold face letters highlight that there was a significant increase in relative performance between rounds 1 and 2, and finally (*) marks the level of significance (5\%). 
Individual researchers, as well as the on-line and printed version of the CERGE-EI Working Papers Series (including their dissemination) were supported from the following institutional grants:

- Economic Aspects of EU and EMU Entry [Ekonomické aspekty vstupu do Evropské unie a Evropské měnové unie], No. AVOZ70850503, (2005-2010);

- Economic Impact of European Integration on the Czech Republic [Ekonomické dopady evropské integrace na ČR], No. MSM0021620846, (2005-2011);

Specific research support and/or other grants the researchers/publications benefited from are acknowledged at the beginning of the Paper.

(c) Jan Hanousek, Evžen Kočenda, 2005

All rights reserved. No part of this publication may be reproduced, stored in a retrieval system or transmitted in any form or by any means, electronic, mechanical or photocopying, recording, or otherwise without the prior permission of the publisher.

Published by

Charles University in Prague, Center for Economic Research and Graduate Education (CERGE) and

Economics Institute (EI), Academy of Sciences of the Czech Republic

CERGE-El, Politických vězňu 7, 11121 Prague 1, tel.: +420 224005 153, Czech Republic.

Printed by CERGE-EI, Prague

Subscription: CERGE-El homepage: http://www.cerge-ei.cz

Editors: Directors of CERGE and EI

Managing editors: Deputy Directors for Research of CERGE and EI

ISSN 1211-3298

ISBN 80-7343-040-1 (Univerzita Karlova v Praze, CERGE)

ISBN 80-7344-029-6 (Národohospodářský ústav AV ČR, Praha) 
CERGE-EI

P.O.BOX 882

Politických vězňů 7

11121 Praha 1

Czech Republic http://www.cerge-ei.cz 